\title{
Teaching In A Silent Classroom:A Case Study
}

\author{
Ariel E. San Jose, PhD \\ Faculty of Foundation Studies, Gulf College, Sultanate of Oman
}

\begin{abstract}
Speaking and hearing play important role in communication and teaching individuals who lack these abilities will experience an uphill struggle. Thus, teaching mute and hard-of-hearing learners is a vocation to serve and a dedication of self.This case study explored the reasons, the struggles, the successes, and insights gained in teaching mute and hard-of-hearing students.It revealed that mute and hard-of-hearing learners had difficulty in learning a language because they had no sense of the language. Interestingly, the main participant learned that normal individuals should be thankful that they were given the gift of hearing and speaking. The role of a college which caters mute and hard-of-hearing learners is of great importance. The college needs to identify qualified teachers who have knowledge on the needs of the mute and hard-or-hearing learners to provide necessary equipment essential for the improvement of their learning; to abide by the state curriculum intended for these learners; to provide compassionate, friendly, and respectful learning environment.
\end{abstract}

Keywords: case study, hard of hearing, mute, special needs

\section{INTRODUCTION}

Teaching students with special needs is one of the most challenging if not the most difficult experience I ever had in my teaching career. My lack of authentic teaching and learning experience in the context of the mute and hard-of-hearing students' literacy program made me feel embarrassed. However, I was not the only person who encountered such a dilemma. Jobling and Moni (2004) observed that pre-service teachers revealed their struggles in teaching students with special needs because they lacked experience, knowledge and understanding of these learners. On the other hand, William and Finnegan (2003) found that a number of mute and hard-of-hearing students are taught in general classrooms by general education teachers who have no or little knowledge on the special needs. They pointed out that these teachers may have never encountered such learners.

These learning situations of the special needs might be the result of neglect on the part of the education policy makers or the curriculum developers. In China, Lytle, Johnson and Hui (2005) observed that though there was a national policy for educating the mute and hard-of-hearing students, it remained an impotent effort because school curricula set low expectations; lack academic contents; lack preparation training for teachers and interpreters. Hence, mute and hard-of-hearing adults find no job. In Britain, Farrell (2001) concerned about three key issues on how to improve special needs education which are categorization of special needs learners; role of legislation; and development of inclusive education.

Several studies which dealt with teaching techniques for students with special needs but few dealt with teacher's experiences in dealing with these learners. The issues presented about may have been experienced by the special need teachers but their voices may not be heard. In this study, I focused intensively on the experiences of a mute and hard-of-hearing teacher; dwelt into his difficulties; and decipher the insights he learned from those experiences. These experiences may be of importance to the policy makers and curriculum developers in shaping the appropriate programs for these kinds of learners. It was in this context that this case study is conducted.

\subsection{Research Questions}

This research determined the experiences of an English teacher exposed to adult mute and hard-of-hearing students. Specifically, this research answered the following questions:

1. What made the participant opted to teach special needs students?

2. What were the experiences of the participant in teaching the special needs students?

3. What insights the participant obtained which he couldshare to other teachers of special needs?

\subsection{Theoretical Lens}

This research was anchored on the theory of Fundamentals of Defectology developed by Lev Vygotsky (Vygotsky, Rieber, and Carton, 1993). This theory proposes a comprehensive and practical oriented paradigm of educating children with special needs (Gindis, 1995). In this theory, Vygotsky views on the nature of disability in children, the principles of psycho-educational evaluation of the disabled, and the issue of the compensation 
and education of children with sensory and cognitive impairments (Groves, 2012).Vygotsky pointed out that a disability is incongruence between the individual's psychological structure and the structure of cultural forms (Rieber and Carton, 1993).

This study was further anchored on the concept of personal experience. Clandinin and Connelly (1994) said that personal experience exposed someone's thoughts as result of a given situation. It could also include narratives of personal accounts brought by a personal encounter. Pope and Gilbert (1983) reiterated that significant learning happened when the "facts" to be learned were construed as having personal significance. Thus, in this study, the personal encounter of the participant was essential in discovering and understanding the nature of a classroom where mute and hard-of-hearing learners were taught.

\section{METHOD}

\subsection{Research Design}

This research used the qualitative case study method.This method was used to 'explore and discover personal insights and understanding' (San Jose, 2012) of a person who lived and experience a certain situation. Moreover, this study used the intrinsic case method because it only involved a single phenomenon, that is, the teaching experiences of an English teacher with the mute and hard-of-hearing learners. Hence, in case study, the emphasis is on what is something to be learned from a single experience. Crowe, Cresswell, Robertson, Huby, Avery, and Sheikh (2011) added that case study is an approach to gather information which involved and allowed in-depth, multi-dimensional exploration of real-life issues in a given setting.

\subsection{Participants}

There were two participants in this study. The first participant was an Egyptian English teacher, who has been teaching students with special needs for almost 25 years. He spent his 20 years in Saudi Arabia, five years in Egypt, and three months in Oman. He was a graduate of BA English and obtained a diploma in sign language. He was married with five children. His entire career was spent teaching special needs students. He was the main participant of this study.The second participant was a Sudani lady. She spent teaching mute and hard-of-hearing students for 11 years. She started her career in Sudan. She joined Gulf College in 2012. She was a BS Business Management graduate and took a one-year certificate in sign language. She was married with two children. She was the confirmer on this study.Both participantswere co-teachers of the researcher. They were assigned in the Special Needs (SN) program. Both function as assistant lecturers. They interpreted into sign language the written and spoken language to the mute and hard-of-hearing learners.

\subsection{Instruments}

To obtain the pertinent answers to the questions, the research made use of the interview guide questionnaire. The questionnaire was subjected for validation from an expert. The guide questionnaire was composed of four main and probe questions. All questions were open-ended so that the participants could elaborate their answers.

\subsection{Design and Procedure}

To make a sound and reliable study, I followed a strict procedure of trustworthiness and ethics. In a qualitative research like this, these issues were always in questions because subjects in a qualitative research limit generalization of the outcomes.

Before conducting an in-depth interview with the participant, an initial permission was asked. The participant was oriented on the nature of the research and the procedures on how it would be conducted. Research questions were given to the participant prior to the conduct of the interview. This was done for him to be orientedof the possible questions. Then, a schedule for the interview was set. The process of asking for permission took three weeks. The time element was important for the participant to reflect as to whether he wanted to continue or not.

Formulation of the research questions was done after the verbal permission was made. The research questions were based on the objectives of the study which were to know what drove the participant to be a teacher of the special needs learners; what were his struggles and successes; and what were the significant insights he obtained from his experiences which could be shared to other special needs teachers. The research questionnaires were subjected to face and content validity by an expert. This was done to make sure that everything included in the study were connected and could be verified. Creswell and Miller (2000) suggested that validity involved researchers' awareness of the study and the kind of case proposal he is going to do.

After the interview, I told the participant that a transcription will be provided for him to verify. I made it clear to the participant that after reading the script, he could delete parts which may endangered or encroached his person. This process of self-verification was important because it addressed the credibility and reliability of the information gathered from the source. Stenbacka (2001) said that reliability is attained when the participant 
of a study has knowledge of the information obtained. Moreover, the participant was assured that the information gathered will be kept with confidentiality by the researcher and can only be used for the purpose of the research. And that his real identity will not be revealed rather a pseudonym will be assigned. The participant was given the pseudonym of Mr. Sign.

Before the information were analyzed and interpreted, I made another interview with an English teacher who was also teaching mute and hard-of-hearing learners. This was conducted to triangulate the information gathered from the main participant. Triangulation as described by Jick (1979) as a 'convergent validation' of information and by Hartley and Sturm (1997) as the 'intersection of two points'. In short, it is an alternative way of confirming the reliability and validity of the information under study. As a researcher, I was compelled to do this because one of the many issues thrown against qualitative research in general and case study in particular was the veracity and confirmability of the information.

In the aspect of dependability of this study, I was certain that the case-participant was credible and knowledgeable about the topic I was exploring. As stated in the profile, the case-participant had been teaching mute and hard-of-hearing learners for more than 25 years in three different countries. Moreover, I made sure that the research questions were consistent with the goals of the study. Gasson (2004) pointed out that dependability of the study is attained if there is a 'consistent manner' of procedures in the conduct of a study, while Polit and Beck (2012) referred to is as the constancy of the data over similar conditions.

In the aspect of transferability, this study may be relevant to other researchers who may explore the significant experiences of teachers who teach other type of learners with autism, blindness, dyslexia, ADHD and others. The information obtained in this research may significantly contribute in understanding the flight of special need teachers. According to Gasson (2004) transferability refers to how the researcher imparted and applied the findings of a study to the reader or other researcher for his own study. Furthermore, in this research I provided sufficient information and thick discussions.

\section{RESULTS}

The purpose of this study was to explore the reason, the experiences, and significant insights of the participant in teaching the mute and hard-of-hearing learners. For the purposes of audit trail, codes were included in the verbatim answers of the participant. SN stood for Special Needs; R for response; L for line and the numbers showed the sequence of the answers.

\subsection{Choosing to Teach Students with Special Needs}

Mr. Sign dedicated his life in teaching the students with special needs because he wanted to make a difference in the lives of these individuals. He wanted to make these learners know basic and significant information about their lives and needs. And with his long experience teaching these learners, he developed compassion and love for them.

"I like to be an interpreter to help special needs or the deaf students to understand the general information about their rights."SNR L1-2

The confirmer believed that teaching the special need learners was a matter of willingness of someone and the love of the sign language. For her, she indulged into teaching the mute and hard-of-hearing because her inclination to the special needs and her adoration to the sign language.

At the meantime, he is an assistance teacher. His role is to translate written words into sign language for the special need students to understand. He was not given a main teaching position because he had no graduate degree as required by Ministry of Manpower and Higher Education. Hence, his job in the classroom is as an interpreter. He is planning to take a graduate degree in special needs for him to have a main teaching position.

"I was a teacher for special needs for more about 25 years. But the

Dean asked us that I must have master. Yeah, if only I have master. I

must be." SNR L12-13

Mr. Sign obtained his skills in interpreting the words after he finished his Diploma in English Sign Language for a year in Egypt. From then on, he engaged himself in teaching English to students with special needs.

"Yes, I finished my Bachelor in English. I study English Sign

Languages in Egypt for one year. I have a certificate. I was an English

teacher in Egypt not interpreter only. Here, I am only an interpreter.

Before, I was teaching."SNR L15-18

The confirmer affirmed that teacher in the special needs do not have degree in special education. She was a BA in Business Management and took one year diploma in sign language. Her diploma allowed her to teach in the special needs. 
For Mr. Sign, mute and hard-of-hearing students were knowledgeable and had the potentials but they lack seriousness. Most of the time, they considered classroom learning as a play.

"I can describe the special needs. They are very good students but they had some problems that they do too much joking and they don't care about anything. I made mistakes and considered them as jokes."SNR L29-31

I personally experienced what Mr. Sign was saying. Whenever I give assignment to the students, they wouldn't do it at home neither they were busy doing it when they arrived at the classroom. Rather, they reasoned out that they forgot to do it. They offered many alibis. However, I also observed that these learners were eager to learn. Though they wanted a shorter activity, they would willingly do the task on their own.

Mr. Sign also mentioned that one of the problems with the mute and hard-of-hearing students was their inability to feel the language. Since the day of their birth, they did not hear the sound of the word; thus, every word became foreign to them.

"They cannot have a sensation about the language. They haven't a sensation about the language. What do you mean by sensation? Taste of the language. When you speak about English, you must taste it. Also, language is tasting. So, teaching language is also tasting a language. Every one of us.All the language. Taste it to understand it. So, they don't understand. Yeah. Also Arabic language, they must taste it. They don't also understand Arabic language. They can write Arabic in the wrong ways. Special needs, because they don't listen to. They didn't hear any language from the time they were born - from the beginning of their lives. They didn't hear anything. How can they taste?"SNR L 32-40

The confirmer agreed that teaching the mute and hard-of-hearing learners were difficulty especially that she was teaching the professional subjects. One of her struggles was on how she could let the learners understand a specific feeling because there is an overlapping interpretation of emotions in sign language specifically with Arabic sign language. She also mentioned of the struggles of the learners in understanding vocabularies which were alien to them.

Mr. Sign added that the mute and hard-of-hearing learners have weak memory. They easily forget the information they obtained from the previous interaction they had. He believed that these learners cannot recall what they were into in the past encounters; hence, the information they had were limited only to what they freshly obtained. Their memoriesare very weak. Why? Memory depends on the information comes from outside. If you didn't have these information, you will not memorize it. You cannot feedback it. SNR L 42-44 Interestingly, mute and hard-of-hearing learners when conversing with each other depends on the information they got from what they had seen recently.

"So, when they are talking with each other, they can talk about the general situations and things which happen in front of them when they are seeing it. They can. But when they can they try it to say what are say what are in their selves inside they cannot. They cannot."SNR L4649

The above situation was quite correct. For several times during writing task, when these mute and hardof-hearing students were asked to write something about what they have done during their vacation or describe their kitchen and living room, they won't respond. Thus, a guided writing with the help of picture strategy they were able to understand the task.

\subsection{Challenges}

Mr. Sign admittedly said that teaching students with special needs was challenging. One of the difficulties he encountered was the lack of laboratory for the mute and hard-of-hearing learners. He believed that this laboratory was significant in element in the acquisition of knowledge among the learners. He shared that in the previous schools, in Saudi Arabia and Egypt, there were speech laboratories.

"We have many difficulties in teaching special needs. There is no laboratory for them. A special lab for them. The laboratorieshave microphone. Some students hear can. Not all of them are completely deaf. They can hear. They can hear sounds. If they have these ear phones, they can hear. We have speech lab in Saudi Arabia and in Egypt. I can't request for this equipment because I am still new here." SNR L51-56 
In dealing with the challenges in teaching the mute and hard-of-hearing learners, Mr. Sign used his gained experiences especially in sign languages. He made sure that the information he conveyed to the learners were correct.

"I can deal with these difficulties for the special needs ahh... by using my experience and teaching them sign language, so that I can give them information, the correct information." SNR L59-61

Mr. Sign was knowledgeable about the universal sign language; he was also aware that sign language would differ from one country to the other. For him, thisdifference was not a big concern.

"Yeah...There are universal sign languages and also special sign languages for each country. Not all. And every time ... there are renew sign language ... We can say renew the sign for some vocabularies. Some changes such as the American in the beginning. First 10 years ago...they said like this... but now they say like this ... This one like gun... using the gun to shoot... America is a power man or a police man ... Now they make like this a United States (putting hands together). SNR L63-67

\subsection{Triumphs}

Mr. Sign proudly admitted that he had many successes in teaching the special needs learners. Though he considered teaching these learners was difficult, he was confident that he became a good instrument in conveying the information to the mute and hard-of-hearing. Knowing how to deal with these learners was already a success and trying to convey to them good information was another.

"Ah, I have many successes in teaching special needs. ..in Egypt... in

Saudi Arabia, also in Oman. I make very good information of experience with these students because these students are so difficult to teach." SNR L69-71

Aside from conveying the correct information, Sign also became a counselor for the mute and hard-orhearing learners. He observed that these learners had self-inferiority with the normal people. He believed that they were always in doubt whenever they saw normal students talking with each other. They thought they were the subject of their conversations. Hence, he explained to them learners that they were wrong.

"I need to keep with them and try to keep them closely. They are thinking that the normal students or the general people or ordinary people who can speak are not good. If you speak about them, they will let you and ask you what you speak? What do you speak about? Every question needs to know because they feel angry because they cannot hear. They thought that they are the subject of the conversation." SNR L71-75

In his words, Sign tried to convince these learners that normal people like them; that normal people don't consider them as inferior rather as special and that normal people don't make fun with them.

"By explaining to them I like you. I want to help you. And I want you to know what other people like speak about. They don't speak about you. They are not joking about you because you are deaf. They are trying to help you because they want you as a natural student. So, I am interpreter to join them with the world outside." SNR L77-82

\subsection{Insights Learned}

For Sign, he learned significant things while teaching the special needs. He acquired new sign languages from them. In a sense, he was thankful because these new sign languages added to his knowledge.

"I learned from them the new signs because they are contact with other special needs in other world. They bring for me the other signs and tell me that it is very good and when I wanted to know any information in new sign from them they can tell me also I can ask them."SNR L86-89

Moreover, Sign learned a very important thing in life - to value what God had given. Encountering these learners made him reflect that normal individuals had no reason to complain. Moreover, he considered teaching the mute and hard-of-hearing learners as opportunity and they were gift from Allah. He thought that he and his children were lucky because they can hear; they can speak; they can communicate with people around him. In short, they were normal.

"I learned the important thing. When I look at my children I say amhamdullah. I considered them as my children. But when I look at my 
children, I feel alhamdullah because they have hearing and speaking. They are gift from Allah. A very good gift from Allah. When you missed these gifts what will you be? Try to imagine yourself without speaking, without hearing. If you are blind man... what can you say?"SNR L90-95

The confirmer was thankful that she was given a change to teach the mute and hard-of-hearing learners. She realized that an interpreter, one needed to know and adapt the local sign language. She was glad that her exposure in teaching other special needs students in different countries made her obtained the local and unique way of sign language communication.

\section{DISCUSSION}

Teaching special needs compassion and patients. Unlike normal learners, special needs learners need extra-attention, mindfulness and care. Theseare needed because special needs learners are facing 'uniquely social-emotional challenges' (Benn, Akiva, Arel and Roeser (2012). Aside from teaching them with knowledge, special needs teachers need to provide safe and gentle learning environment (McGee, Menousek and Menolascino (1998). If compassion is present in the special needs classroom there is lower stress levels because learners see themselves as competent (Williams, 2001). Thus, special needs students will be persistent in their endeavor to learn (Demik, 2008). In context of this study, Mr. Sign is able to realize the needs of his special needs students through not necessary he show compassion and patience. His aim of teaching the mute and hardof-hearing learners was to let them acquire knowledge and understanding of the lessons.

Shortage of qualified special needs teachers remained to be a problem in recent times (Brownnell, Ross, Colon and McCalum, 2005 and Demik, 2008).This shortage was intensified by the new demands and high attrition levels (Thornton, Pelier and Edina, 2007). The cause of this problem is the inadequate working conditions, teachers' burnout, and sub-standard quality of education for special needs students (Fore, Martin and Bender (2002). As a result, most of the schools which cater special needs students hire non-special needs teachers. This in turn adds to the already problematic conditions. In the case of the Gulf College, Mr. Sign, a BA English graduate with sign language certificate is hired to teach mute and hard-of-hearing students.

Deaf and hard-of-hearing teachers have a tag-of-war battle in teaching their students. This is because of the realities that they need to encounter and understand among their learners. According to Power and Leigh (2000) deaf learners experience nuances when they read texts; thus, hinder their comprehension.Gogate, Rishikeshi, Mehata, Ranade, Kharat and Deshpande (2009) found that ocular problems are common to this type of learners. They agreed with Power and Leigh (2000) that mute and hard-of-hearing learners have poor auditory sense. On the other hand, Barker (2003) stated that deficit in vocabulary among mute and hard-of-hearing students has hampered their literary and interaction with others.

In the context of this study, Mr. Sign says that his mute and hard-of-hearing students are knowledgeable but lack seriousness. This lack of focus may be the result of their impairment in visual and auditory. Their interest in learning is hindered by what and how they fell. In dealing with the mute and hard-ofhearing learners, Mr. Sign says that he applies his gained knowledge in sign languages. He sees to it that he conveys the right information to the learners. This endeavor is favored by many literatures which state that fluency in the sign language on the part of the teachers definitely help in the cognition of the mute and hard-ofhearing learners.

On the concern about the equipment needed for the teaching of the mute and hard-of-hearing learners, providing a communication device for mute and hard-of-hearing learners is of big significance. Butnaru and Krueger (2001) patented the communication device which allows the hard-of-hearing learners to visualize speech and other sounds feed on them through various audio sources. Zhao, Lirong, Chao, Lijuan, and Jia (2010) in their laboratory experiment shows that 3D visual-speech method can help mute and hard-of-hearing learners determine the different position by comparing the standard speech database parameters and sequence parameters of learners' pronunciation. Thus, provide intuitionist information feedback for the learners to improve the quality of their pronunciations. Thus, the mention of Mr. Sign to put a special laboratory for the mute and hard-of-hearing learners may a good interventionto improve the speech and hearing abilities of the learners. Another challenge teachers' face in dealing with the mute and hard-of-hearing learners is selfconfidence. Wun (1997) found that anxiety, lack of self-worth, hostility and dependence are common among deaf and hard-of-hearing individuals. Yuping (2000) added that deaf and hard-of-hearing learners have certain mental problems and their level of anxiety is higher compare to the normal students. Glickman (2009) found that deaf and hard-of-hearing persons were usually referred to psychiatric hospitals. While Fellinger, Holzinger, and Pollard (2012) stated that deaf persons are usually experiencing high probability of complex mental health needs. To solve these problems, family members, friends, and teachers need to provide psychological support. Thus, what Mr. Sign is doing to his students of extending his time is good. 
Deaf and hard-of-hearing teachers have unique teaching experience with their learners compared to those who are in the mainstream classrooms. From these personal experiences they are able to gain significant insights which are beneficial in their professions. In the book, "Seeing Voices" of Sacks (1990)recognized and respected the courageous struggles of the mute and hard-or-hearing individuals. In the study of Vermeulen, Denessen and Knoors (2012) they observed that teachers showed consideration to their mute and hard-ofhearing students but less patience to those students with negative work attitude. In the later study, Howard (2003) pointed out in his insightful findings that parents' guidance was necessary; perceptions of teachers and counselors need to should favor the learners; and the role of the college. He further stressed that mute and hardor-hearing learners were marginalized individuals who struggle to correct the failure of the school.

In the context of this study, Mr. Sign's insights somewhat coincides with Sack (1990). Mr. Sign knows the struggle of his mute and hard-or-hearing learners and the best he can do is to accept and respect them the way they are. But more than that, he is able to overturn his idea by recognizing the power of God. He was grateful that he is normal and so his children. His recognition of God reflects his faith which helps to continue with his job. On the other hand, Mr. Sign also becomes his students' counselor and that he learns from them. It shows that Mr. Sign has fully understands the nature of his learners, so that he decides to dedicate his life teaching them.

\section{CONCLUSION}

Speaking and hearing play important role in communication and teaching individuals who lack these abilities is an uphill struggle. Thus, teaching mute and hard-of-hearing learners is a vocation to serve and a dedication of self. The role of the college which caters mute and hard-of-hearing learners is of great importance. The college needs to identify qualified teachers who have knowledge on the needs of the mute and hard-or-hearing learnersto provide necessary equipment essential for the improvement of their learning; to abide by the state curriculum intended for these learners; to provide compassionate, friendly, and respectful learning environment. The experiences of Mr. Sign dealing with the mute and hard-of-hearing learners are just a pinch of a broader spectrum. However, his experience is of significance to other teachers who dedicate their lives teaching these kinds of learners. Thus, his story is of significant contribution to his profession.

\section{REFERENCES}

[1] Jobling, A. and Moni, K.B., (2004). 'I never imagined I'd have to teach these children': providing authentic learning experiences for secondary pre-service teachers in teaching students with special needs. Asia-Pacific Journal of Teacher Education, 32(1), pp.5-22.

[2] Williams, C.B. and Finnegan, M., (2003). From myth to reality: Sound information for teachers about students who are deaf. Teaching Exceptional Children, 35(3), p.40.

[3] Lytle, R.R., Johnson, K.E. and Hui, Y.J., (2005). Deaf education in China: History, current issues, and emerging deaf voices. American Annals of the Deaf, 150(5), pp.457-469.

[4] Farrell, P., (2001). Current issues in special needs: Special education in the last twenty years: have things really got better?. British Journal of Special Education, 28(1), pp.3-9.

[5] Vygotsky, L.S., Rieber, R.W. and Carton, A.S., (1993). The collected works of LS Vygotsky: the fundamentals of defectology (Vol. 2). Springer Science \& Business Media.

[6] Gindis, B., (1995). The social/cultural implication of disability: Vygotsky's paradigm for special education. Educational Psychologist, 30(2), pp.77-81.

[7] Groves, J.A., (2012). Acquired Learning Disorders in Children: A Neuropsychological-

Rehabilitation. Cognitive Science: Contributions to Educational Practice, 63, p.255.

[8] Rieber, R.W. and Carton, A.S., (1993). Introduction: The fundamental problems of defectology. In The collected works of LS Vygotsky (pp. 29-51).Springer US.

[9] Clandinin, D.J. and Connelly, F.M., (1994). Personal experience methods.

[10] Pope, M. and Gilbert, J., (1983). Personal experience and the construction of knowledge in science. Science education, 67(2), pp.193-204.

[11] San Jose, A.E., (2012). Linguistic Experiences of Adult Dyslexic Learners. UIC Research Journal, 18(1).

[12] Crowe, S., Cresswell, K., Robertson, A., Huby, G., Avery, A. and Sheikh, A., (2011). The case study approach. BMC medical research methodology, 11(1), p.1.

[13] Creswell, J. W. \& Miller, D. L. (2000). Understanding reliability and validity in qualitative research. Retrieved from http://staf.cs.ui.ac.id/WebKuliah/TKSI/Understanding\%20Realibility\%20in\%20Qualitative\%20Research. pdf 
[14] Stenbacka, C., (2001). Understanding reliability and validity in qualitative research. Retrieved from http://staf.cs.ui.ac.id/WebKuliah/TKSI/Understanding\%20Realibility\%20in\%20Qualitative\%20Research. pdf

[15] Jick, T.D., (1979). Mixing qualitative and quantitative methods: Triangulation in action. Administrative science quarterly, 24(4), pp.602-611.

[16] Hartley, R.I. and Sturm, P., (1997). Triangulation. Computer vision and image understanding, 68(2), pp.146-157.

[17] Gasson, S., (2004). Rigor in grounded theory research: An interpretive perspective on generating theory from qualitative field studies. The handbook of information systems research, pp.79-102.

[18] Polit, D.F. and Beck, C.T., (2012). Resource manual for nursing research.

[19] Benn, R., Akiva, T., Arel, S. and Roeser, R.W., (2012). Mindfulness training effects for parents and educators of children with special needs.Developmental Psychology, 48(5), p.1476.

[20] McGee, J., Menousek, P. and Menolascino, F.J., (1988). Gentle teaching. Shawnee Press (PA).

[21] Williams, K., (2001). Understanding the Student with Asperger Syndrome Guidelines for Teachers.Intervention in School and Clinic, 36(5), pp.287-292.

[22] DeMik, S.A., (2008). Experiencing attrition of special education teachers through narrative inquiry.The High School Journal, 92(1), pp.22-32.

[23] ${ }^{[23]}$ Brownell, M. T., Ross, D. D., Colón, E. P., \& McCallum, C. L. (2005). Critical features of special education teacher preparation a comparison with general teacher education. The Journal of Special Education, 38(4), 242-252.

[24] Thornton, B., Peltier, G. and Medina, R., (2007). Reducing the special education teacher shortage.The Clearing House: A Journal of Educational Strategies, Issues and Ideas, 80(5), pp.233-238.

[25] Fore, C., Martin, C. and Bender, W.N., (2002). Teacher burnout in special education: The causes and the recommended solutions. The High School Journal, 86(1), pp.36-44.

[26] Power, D. and Leigh, G.R., (2000). Principles and practices of literacy development for deaf learners: A historical overview. Journal of Deaf Studies and Deaf Education, 5(1), pp.3-8.

[27] Gogate, P., Rishikeshi, N., Mehata, R., Ranade, S., Kharat, J. and Deshpande, M., (2009). Visual impairment in the hearing impaired students. Indian journal of ophthalmology, 57(6), p.451.

[28] ${ }^{[28]}$ Barker, L.J., (2003). Computer-assisted vocabulary acquisition: The CSLU vocabulary tutor in oraldeaf education. Journal of Deaf Studies and Deaf Education, 8(2), pp.187-198.

[29] Butnaru, H. and Krueger, W.D. (2001). Communication device and method for deaf and mute persons. Retrieved

[Online] https://www.google.com.om/patents/US6240392?dq=equipment+for+deaf+and+mute+learners $\& h l=e n \& s a=X \& v e d=0 a h U K E w i K x J z 02 \_L N A h W I n B o K H Q S H D r w Q 6 A E I K j A B$

[30] Zhao, J., Lirong, W., Chao, Z., Lijuan, S. and Jia, Y., (2010, August). Pronouncing Rehabilitation of Hearing-impaired Children based on Chinese 3D Visual-speech Database. In 2010 Fifth International Conference on Frontier of Computer Science and Technology (pp. 625-630).IEEE.

[31] Wun, D., (1997). The analysis and interference research on psychological crisis of the deaf students in schools for deaf and mute. Chinese Journal of Special Education., 4, p.008.

[32] Yuping, L., (2000). Initial Investigation of Mental Health of Deaf-mute Students [J]. Chinese Journal of Special Education, 4, p.003.

[33] Glickman, N.S., (2009). Adapting best practices in CBT for deaf and hearing persons with language and learning challenges. Journal of Psychotherapy Integration, 19(4), p.354.

[34] Fellinger, J., Holzinger, D. and Pollard, R., (2012). Mental health of deaf people. The Lancet, 379(9820), pp.1037-1044.

[35] Sacks, O., (1990). Seeing voices: A journey into the world of the deaf.

[36] Vermeulen, J.A., Denessen, E. and Knoors, H., (2012). Mainstream teachers about including deaf or hard of hearing students. Teaching and Teacher Education, 28(2), pp.174-181.

[37] Howard, T.C., (2003). "A tug of war for our minds:" African American high school students' perceptions of their academic identities and college aspirations. The High School Journal, 87(1), pp.4-17. 